\title{
Metallurgical Processing of Al-Si Alloys with Increased Iron Content Using Sodium, Strontium, and Tellurium
}

\author{
Marcela Pokusováa*, Igor Berta ${ }^{a}$, Marta Murgašováa \\ aSlovak University of Technology in Bratislava, Faculty of Mechanical Engineering, Nám. slobody 17, 81231 Bratislava, Slovakia \\ ${ }^{*}$ e-mail: marcela.pokusova@stuba.sk
}

Received: 8 October 2017/Accepted: 2 February 2018/Published online: 30 March 2018

This article is published with open access at AGH University of Science and Technology

\begin{abstract}
This paper presents the results of research focused on the processing of the hypoeutectic Al-Si alloy with an increased iron content of $1.75 \mathrm{wt} . \%$. The physical-metallurgical method was used to eliminate the undesirable effect of the iron rich $\beta$-phase on the mechanical properties of the casting material using liquid metal modification by strontium, sodium, and tellurium. The chemical composition of an experimental material didn't contain any elements for the solid-solution strengthening of a matrix; therefore, the presented results can document the capabilities of modifying the $\beta$-phase under a minimum influence on the properties of the basic Al-Si system.
\end{abstract}

\section{Keywords:}

Al-Si alloy, iron, metallurgical processing, sodium, tellurium, strontium

\section{INTRODUCTION}

Today, aluminum alloy casting has come to a stage when a large share of the materials for casting is comprised of scrap metal coming from repair shops or separate collection. The scrap metal introduces lots of the non-metallic inclusions and undesirable impurities into the molten metal due to the fact that the casting's mechanical properties are worsened. As with most used cast materials such as Al-Si alloys, the presence of iron (which cannot be removed in an economically acceptable way) has a negative effect on their mechanical properties. When the iron content is higher than $0.7 \mathrm{wt} . \%$, the brittle and hard bi- and tri-component phases containing Fe rise in the structure, and especially the negative effects are shown by the $\beta$-phase $\mathrm{Al}_{5} \mathrm{FeSi}$ [1-4]. It has the shape of long massive needles, which substantially reduce the strength and ductility of material and worsen the machinability of the material. To modify this adverse shape of the $\beta$-phase $\mathrm{Al}_{5} \mathrm{FeSi}$, in practice, alloying is applied by transition metals such as $\mathrm{Mn}, \mathrm{Cr}, \mathrm{Mo}, \mathrm{Nb}$, Co. However, if the iron content is above $0.7 \mathrm{wt} . \%$, it is necessary to bring a mass of alloying additions into the material, resulting in a change in the alloy's basic properties [5-7]. As mentioned in works $[1,8]$, besides the transition metals, the modifying effect on the $\beta$-phase morphology or its properties towards a matrix has also been proven by elements such as $\mathrm{S}, \mathrm{Te}$, and $\mathrm{Se}$ as well as $\mathrm{Li}, \mathrm{Na}$, and $\mathrm{Sr}$. The advantage of sulfur and tellurium is that they enter preferentially into the $\beta$-phase (and into the main components of the Al-Si alloy only in a very low quantity) [8]. Sodium and strontium are commonly applied modifiers for these alloys, and their modifying effect on the $\mathrm{Al}_{5} \mathrm{FeSi}$ phase attributes to them as surface-active substances [9-11].
This paper presents the results of experiments focusing on opportunities to use tellurium, strontium, sodium, and salts with refining and modifying effects to treat Al-Si alloys contaminated by iron up to $1.75 \mathrm{wt} . \%$.

\section{CONTROL OF IRON'S DETRIMENTAL EFFECT ON AI-Si ALLOYS}

During solidification of the Al-Si alloys with an iron content of at least $0.7 \mathrm{wt} . \%$, more bi- and tri-component phases arise following the stabile diagram of the Al-Si-Fe system presented in Figure 1 [1]. From the diagram, it is apparent that, besides the basic component $\mathrm{Al}$ and $\mathrm{Si}$, the alloy structure contains the $\beta$-phase $\mathrm{Al}_{5} \mathrm{FeSi}$. It has the shape of long coarse needles, which significantly reduce the strength and ductility of alloy and worsen the material's machinability [12]. To change this adverse shape into a more-favorable polyhedral one, this is commonly performed in practice by alloying with transient metals ( $\mathrm{Mn}, \mathrm{Cr}, \mathrm{Mo}, \mathrm{Nb}, \mathrm{Co})$.

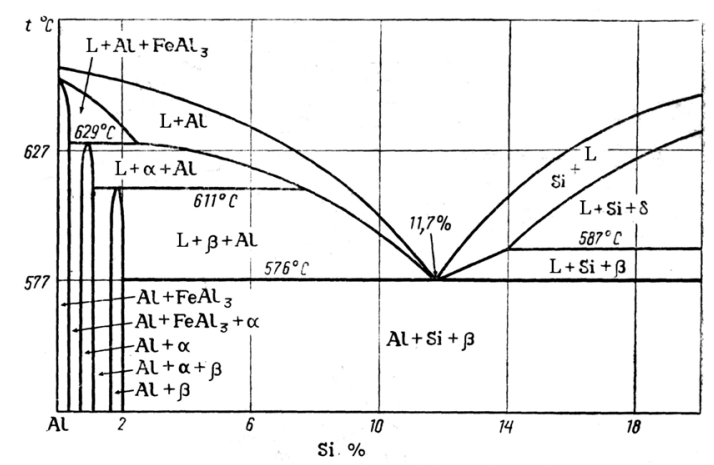

Fig. 1. Phase diagram of $\mathrm{Al}-\mathrm{Fe}-\mathrm{Si}$ at 0.7 wt.\% $\mathrm{Fe}: \alpha-\mathrm{Al}_{8} \mathrm{SiFe}_{2}$, $\beta-\mathrm{Al}_{5} \mathrm{SiFe} ; \delta-\mathrm{Al}_{4} \mathrm{Si}_{2} \mathrm{Fe}$ [1] 
Manganese, the usual characteristic component of $\mathrm{Al}-\mathrm{Si}$ alloys, is used most often [3, 5-7, 13]. Its content must be slightly higher than the iron content; when the total amount $\mathrm{Mn}+\mathrm{Fe}$ is less than $0.8 \mathrm{wt}$.\%, they form the complex $(\mathrm{MnFe})_{3} \mathrm{Si}_{2} \mathrm{Al}_{15}$ phase, which has the characteristic morphology of irregular sticks (the so-called Chinese character). If the total content of $\mathrm{Mn}+\mathrm{Fe}$ is more than $0.8 \mathrm{wt} . \%$, this intermetallic phase is of a regular hexagonal shape. Both morphologies of the $(\mathrm{MnFe})_{3} \mathrm{Si}_{2} \mathrm{Al}_{15}$ phase have only a little effect on the plastic properties of AlSi10 alloys; nevertheless, the modifying effect of $\mathrm{Mn}$ and other transition metals is low. If the iron content is higher than $0.7 \mathrm{wt} . \%$, a lot of alloying additions has to be added to the alloy, which can result in changing its basic properties. In addition, the high content of transition metals would be an obstacle for the later treatment of scrap materials [14].

In general, the shape alteration of an undesirable phase can be done either by physical-metallurgical intervention into the kinetics of its evolution and growth or by supplementing such substances that will enter this phase preferably and generate a change in its shape to a less-negative one. Favorable conditions are offered by specific characteristics of the Al matrix, such as the very low solubility of many appropriate active elements in the solid and liquid phases and by the formation of compounds that are on the right side of the binary diagrams. Therefore, the research was aimed at choosing an element that, at the trace amounts, would produce a change in the iron rich phase shape and would not have a negative effect on the basic alloy. The results have shown that the presence of a very small quantity of VI-group elements as such sulfur, selenium, or tellurium can cause that the $\mathrm{Al}_{5} \mathrm{FeSi}$ phase crystallizes into shorter needle or polyhedral shapes [8]. The special positive modifying effect was reached by adding sulfur of a 0.03 wt.\%. The next experiments have proven that an amount of $0.1 \mathrm{wt} . \%$ of sulfur or $0.2 \mathrm{wt} . \%$ of tellurium can completely suppress the rising of plate shapes and produce the $\mathrm{Al}_{5} \mathrm{FeSi}$ phase crystallization into polyhedral shapes.

In work [8], the authors described a method based on modification with sulfur and additionally with slag, which resulted in additional significant improvement in the mechanical properties of the scrap Al-Si alloy of the AK9 type, even in an industrial range. When the modification with sulfur was applied, the biggest problem was introducing sulfur into the liquid metal. In practice, it was proven that, from the technical point of view, the appropriate way is electrolytic releasing into the liquid metal; however, this requires a separate technological unit that would operate continually or in a batch process. Tellurium is environmentally and applicably positive for its physical properties (density $6.24 \cdot 10^{3} \mathrm{~kg} \cdot \mathrm{m}^{-3}$, melting temperature $723 \mathrm{~K}$, and boiling point $1262 \mathrm{~K}$, while sulfur density is $2 \cdot 10^{3} \mathrm{~kg} \cdot \mathrm{m}^{-3}$ and boiling point $717 \mathrm{~K}$ ). From a wide spectrum of possibilities for altering the characteristics of iron-contaminated Al-Si alloys, the authors have chosen to verify the effect of the metallurgical processing of a model alloy Al-Si-Fe by using refining salt, sodium, tellurium, and strontium, and by the combined treatment with refining salt, tellurium with sodium, and tellurium with strontium.

\section{EXPERIMENTAL WORKS}

For the experiments, the commercially used ENAC-44200 $\mathrm{Al}-\mathrm{Si}$ alloy for casting was used, which has the following chemical composition: Si 12.89, Cu 0.03, Mn 0.18, Zn 0.0009, Fe 0.3, Ti 0.12, Mg 0.04 (all in wt.\%). This alloy was selected from other deliveries because the main demand was the content of elements as $\mathrm{Mg}, \mathrm{Cu}, \mathrm{Zn}$, and $\mathrm{Ti}$ to be deeply enough below the limit when they can be involved in the solid-solution strengthening or precipitation hardening of the $\alpha$-aluminum solid solution. To introduce the iron into the liquid metal, master alloy EN 575 - AlFe10 of a composition of $0.22 \mathrm{Si}, 10.71 \mathrm{Fe}, 0.03 \mathrm{Cu}, 0.06 \mathrm{Mn}, 0.008 \mathrm{Mg}$, $0.03 \mathrm{Zn}, 0.06 \mathrm{Ti}$ (all in wt.\%) intended for iron alloying the die casting Al-Si alloys was utilized. Charging the master alloy AlFe10 of 17 wt.\% into the mentioned alloy, the experimental material with an iron content of about $1.75 \mathrm{wt} . \%$ and an silicon content of about $9 \mathrm{wt} . \%$ was prepared.

The aims of the experimental works were set up so to give the first picture of the capabilities of metallurgical treating the basic system AlSi9 with 1.75 wt.\% Fe with the graded content of sodium, strontium, or tellurium, and further with their combination when the liquid metal was treated with $0.06 \mathrm{wt} . \% \mathrm{Sr}$ and the graded content of tellurium or with $0.05 \mathrm{wt} . \% \mathrm{Na}$ and the graded tellurium content (Tab. 1).

Table 1

Metallurgical treatment of liquid metal and average values of mechanical properties of studied alloy

\begin{tabular}{cccccccc}
\hline Heat & $\begin{array}{c}\text { Na, } \\
\text { wt.\% }\end{array}$ & $\begin{array}{c}\mathbf{S r} \text { wt.\% } \\
\text { wt }\end{array}$ & $\begin{array}{c}\text { Te, } \\
\text { wt.\% }\end{array}$ & $\begin{array}{c}\boldsymbol{R}_{\boldsymbol{m}^{\prime}} \\
\mathbf{M P a}\end{array}$ & $\begin{array}{c}\mathbf{A 5} \\
\mathbf{\%}\end{array}$ & $\begin{array}{c}\boldsymbol{R}_{\boldsymbol{m} \text { Ts' }} \\
\mathbf{M P a}\end{array}$ & $\begin{array}{c}\mathbf{A 5}_{\text {TS' }} \\
\mathbf{\%}\end{array}$ \\
\hline T5 & - & - & - & 99 & 1.6 & 115 & 1.87 \\
\hline T7 & - & - & 0.075 & 111 & 1.25 & 117 & 1.74 \\
\hline T10 & - & - & 0.1 & 143 & 1.22 & 142 & 1.35 \\
\hline N2 & 0.02 & - & - & 127 & 0.6 & 133 & 1.45 \\
\hline N3 & 0.035 & - & - & 132 & 2.4 & 132 & 2.1 \\
\hline N5 & 0.05 & - & - & 156 & 2.6 & 141 & 2.4 \\
\hline NT5 & 0.05 & - & 0.05 & 104 & 1.27 & 107 & 2.2 \\
\hline NT7 & 0.05 & - & 0.075 & 123 & 1.1 & 114 & 2.8 \\
\hline NT10 & 0.05 & - & 0.1 & 152 & 2.24 & 156 & 2.1 \\
\hline S2 & - & 0.02 & - & 108 & 1.5 & 127 & 1.85 \\
\hline S4 & - & 0.04 & - & 113 & 1.2 & 106 & 2 \\
\hline S6 & - & 0.06 & - & 124 & 1.8 & 127 & 0.8 \\
\hline ST5 & - & 0.06 & 0.05 & 100 & 1.2 & 116 & 1.9 \\
\hline ST7 & - & 0.06 & 0.075 & 112 & 1.9 & 124 & 1.3 \\
\hline ST10 & - & 0.06 & 0.1 & 118 & 1.7 & 122 & 2 \\
\hline NT10 & 0.05 & - & 0.1 & 152 & 2.24 & 156 & 2.1 \\
\hline S2 & - & 0.02 & - & 108 & 1.5 & 127 & 1.85 \\
\hline S4 & - & 0.04 & - & 113 & 1.2 & 106 & 2 \\
\hline S6 & - & 0.06 & - & 124 & 1.8 & 127 & 0.8 \\
\hline ST5 & - & 0.06 & 0.05 & 100 & 1.2 & 116 & 1.9 \\
\hline ST7 & - & 0.06 & 0.075 & 112 & 1.9 & 124 & 1.3 \\
\hline ST10 & - & 0.06 & 0.1 & 118 & 1.7 & 122 & 2 \\
\hline & & & & & & & \\
\hline
\end{tabular}


The criterion of the metallurgical processing efficiency were the results of tensile tests of the as-cast samples of $\phi 10 \mathrm{~mm}$ according to the STN EN ISO 6892-1 standard, which were poured into eight pieces into self-hardening phenol-formaldehyde sand molds (Fig. 2). The weight of the metal in the mold was about $1.1 \mathrm{~kg}$, and heats were performed in a batch of about $1.3 \mathrm{~kg}$ in an LK 312.0 electrical resistance furnace preheated at a temperature of $850^{\circ} \mathrm{C}$.

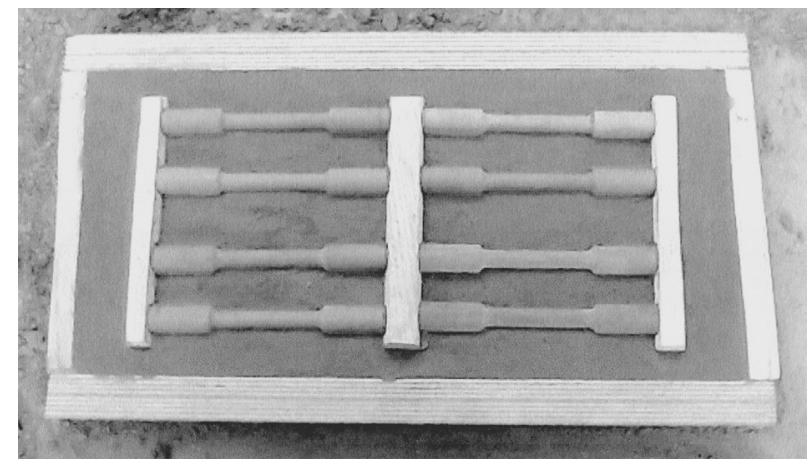

Fig. 2. Odd-side mold with patterns of eight tensile test samples and partial running system

A melting time of about 45 minutes was determined by the period of melting of the master AlFe10 alloy. The mold with the reference samples was poured (Heat E) from the liquid metal, which was subject only to gravity separation for a holding period of seven minutes after being removed from the furnace. For the next heats, the liquid metal was treated by Schäffer AB6 refining salt flux in an amount of 0.1 wt.\% (about $1.3 \mathrm{~g}$ ); then, after the flux acting about one minute and cleaning the molten metal surface, the refining additions shown in Table 1 were introduced for the individual groups of heats. The sodium metal and tellurium were submerged into the metal being wrapped in aluminum foil, and refining salt was applied on the molten metal surface.

After charging the addition and holding for about six minutes, the liquid metal surface was cleaned off, and at a temperature of $640^{\circ} \mathrm{C}$ (measured by digital device ALMEMO 22 90-1), the pouring proceeded. In total, 16 heats were carried out, when 8 test samples were cast at each heat, 4 of which were heat treated. The purpose of the heat treatment was to verify the possible effects of the solution heat treatment [15], particularly on the $\mathrm{Al}_{5} \mathrm{FeSi}$ phase modified by the expected occurrence of tellurium or as a result of treating with sodium or strontium (because the modification effect on the main alloy phases was not presumed). Immediately after pouring, the samples intended for heat treatment were subjected to solution heat treatment at a temperature of $530 \pm 5^{\circ} \mathrm{C}$ with a dwell of 3 hours, followed by quenching in water of $20 \pm 5^{\circ} \mathrm{C}$ and artificial aging at a temperature of $180 \pm 5^{\circ} \mathrm{C}$ with a dwell of 9 hours, and free air cooling. All of the samples (in the as-cast state and heat treated) were put to tensile tests on an EU40 universal tensile testing machine. The average values of tensile strength $R_{m}$ and ductility A5 calculated from the measured ones for the as-cast samples as well as values $R_{m \mathrm{TS}}$ and $\mathrm{A} 5_{\mathrm{TS}}$ for the heat-treated ones are listed in Table 1.

\section{METALLOGRAPHIC ANALYSIS AND DISCUSSION OF RESULTS}

From values of the mechanical properties given in Table 1, it can be seen that all of the investigated methods of metallurgical processing resulted in an improvement in strength (and some of them had increased ductility as well). The metallographic analysis was done with samples selected from the test specimens poured at the individual heats.

The microstructure of the reference as-cast material (Heat E) documented in Figure 3a is typical of the hypoeutectic Al-Si alloy with an iron content of $1.75 \mathrm{wt} . \%$. It is dendritic with rod-like shapes of the eutectic silicon in an aluminum matrix and with the massive needles of the $\mathrm{Al}_{5} \mathrm{FeSi}$ phase that are going across more dendrites. Increasing the amount of the introduced sodium caused a rise in the values of the tensile strength $R_{m}$ and ductility A5 when the highest values of $R_{m}$ at $156 \mathrm{MPa}$ and $\mathrm{A} 5$ at $2.6 \%$ were achieved after applying 0.05 wt.\% sodium for the as-cast state. A modification by sodium of $0.05 \mathrm{wt} . \%$ caused the formation of the characteristic eutectic with very fine particles of silicon, and (what is important) the $\mathrm{Al}_{5} \mathrm{FeSi}$ phase morphology was significantly changed from the coarse structures to fine and much shorter ones (Fig. 3c). Such a character of the microstructure corresponds to the good mechanical properties of the material from the N5 heat and can be attributed to increasing the surface tension and beginning the solidification with considerable undercooling after the sodium processing [1].

The application of strontium has proven likewise, though the $\mathrm{Al}_{5} \mathrm{FeSi}$ phase refinement was considerably less pronounced (Fig. 3e), which could be attributed to the lower undercooling after the strontium processing during the solidification as compared to sodium $[15,16]$. At the heat T10, the modification with tellurium of $0.1 \mathrm{wt} \%$ caused a significant refinement and change in the morphology of the original needle $\mathrm{Al}_{5} \mathrm{FeSi}$ phase (Fig. $3 \mathrm{~b}$ ) when the shape of the main components of the Al-Si alloy (the solid solution $\alpha$ and eutectic) was like the reference material in Figure 3a. Although the material from the heat T10 reached a strength of $143 \mathrm{MPa}$, a ductility higher than the reference one was exhibited by the alloy from the heat $\mathrm{T} 5$ treated with the addition of $0.05 \mathrm{wt} . \% \mathrm{Te}$.

The simultaneous processing with $\mathrm{Na}$ and $\mathrm{Te}$ (heat NT10) caused a shortening of the $\mathrm{Al}_{5} \mathrm{FeSi}$ phase, though it also resulted in a coarsening of the eutectic silicon. Both changes (the $\mathrm{Al}_{5} \mathrm{FeSi}$ phase refining and eutectic Si coarsening) can be considered as having the opposite effect on the mechanical properties. These structure components have very similar morphologies and can be identified using the appropriate etching agent for making them visible. On the material from the heat NT10 treated with sodium and tellurium, tellurium had apparently the dominant influence because the structure (Fig. 3d) is morphologically closer to the structure from the heat T10 modified with only tellurium (Fig. 3b). The application of the combined addition of $0.05 \mathrm{wt} . \%$ sodium with the graded tellurium content has shown this method of treatment did not affect the alloy additively but synergically. 
a)

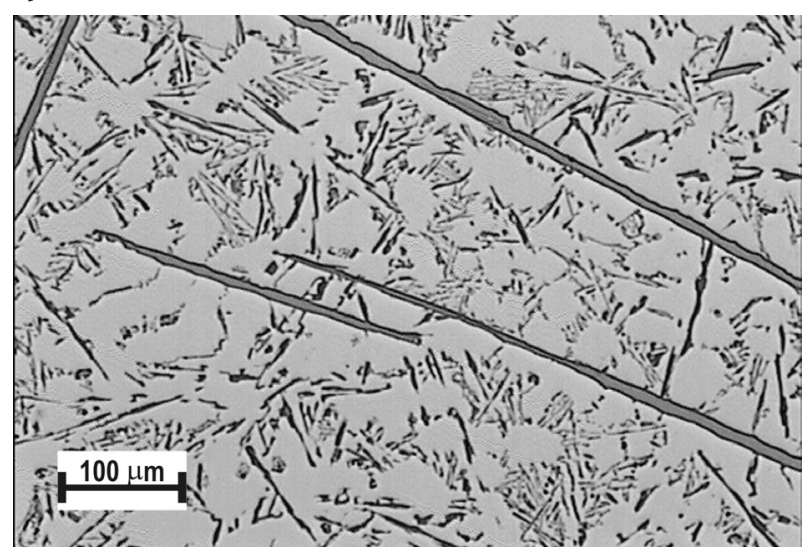

c)

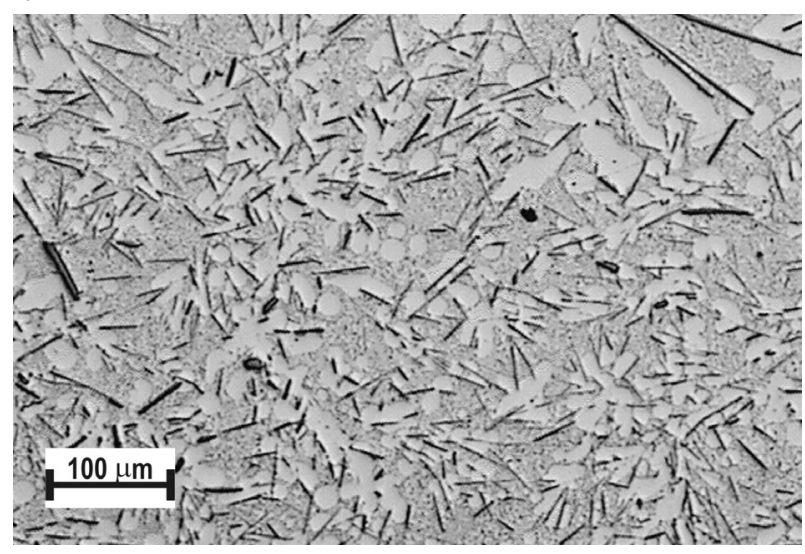

e)

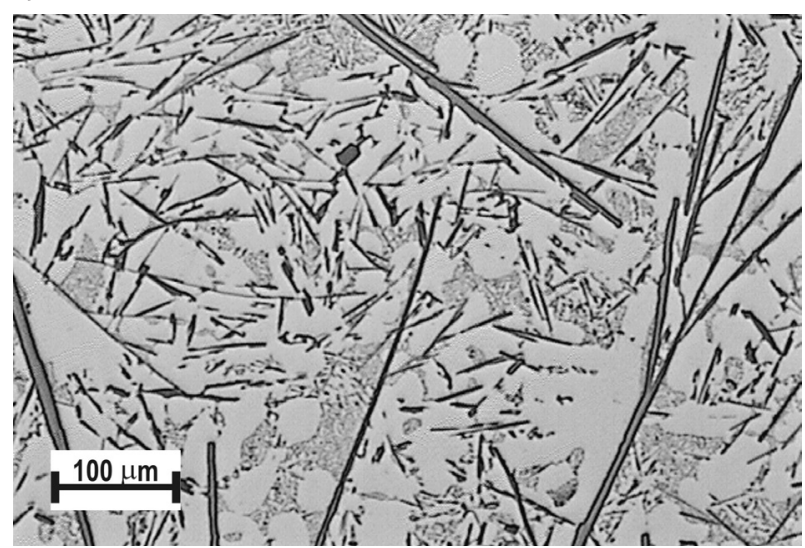

b)

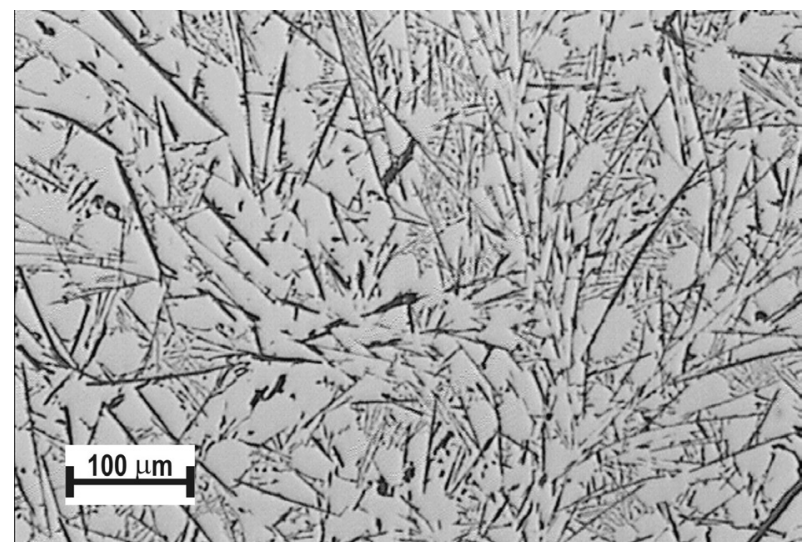

d)

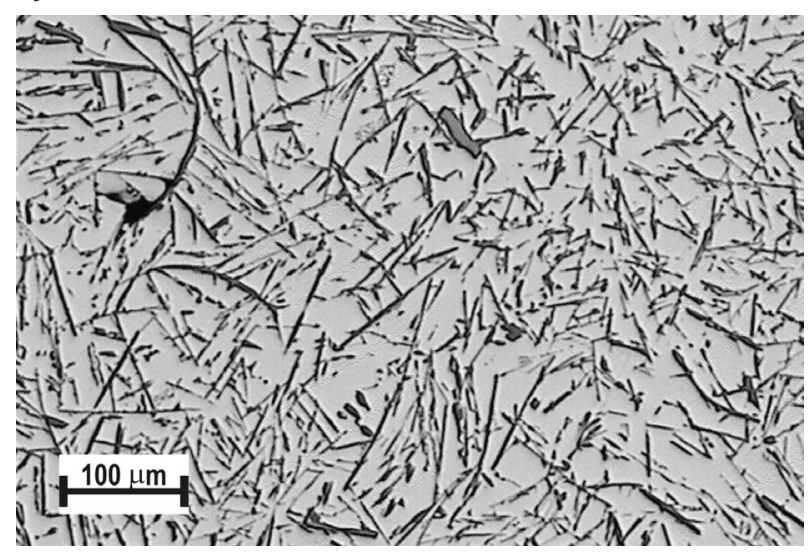

f)

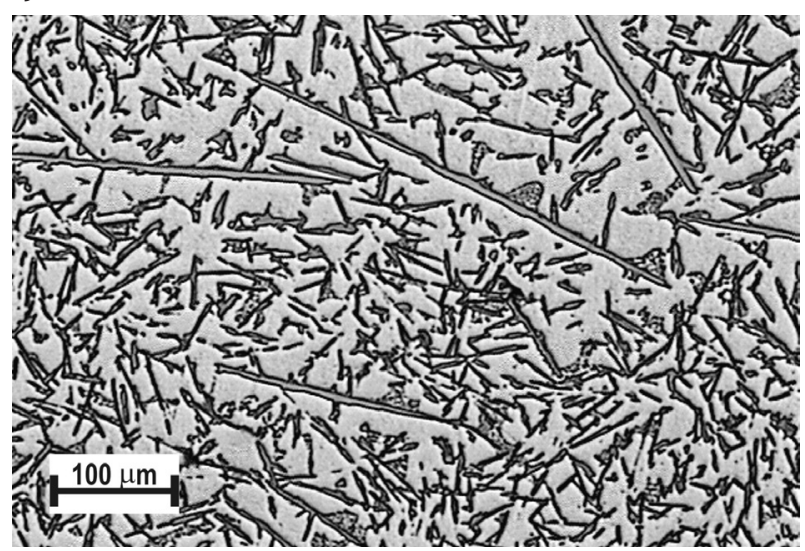

Fig. 3. Microstructure of Al-Si alloy with iron content of $1.75 \mathrm{wt} . \%$ under different metallurgical treatment: a) reference (E); b) $0.1 \%$ Te (T10); c) $0.05 \% \mathrm{Na}(\mathrm{N} 5)$; d) $0.05 \% \mathrm{Na}+0.1 \% \mathrm{Te}$ (NT10); e) $0.06 \% \mathrm{Sr}$ (S6); f) $0.1 \% \mathrm{Te}+0.06 \% \mathrm{Sr}$ (ST10)

Introducing the combinations of $0.05 \mathrm{wt} . \% \mathrm{Na}+0.05$ wt.\% Te or 0.05 wt.\% $\mathrm{Na}+0.75$ wt.\% Te into the liquid metal produced an evident worsening of the mechanical properties as compared with the alloy treated only with $0.05 \mathrm{wt}$.\% sodium at the heat N5. Only when $0.1 \mathrm{wt} . \%$ tellurium was charged into the molten metal being treated firstly with $0.05 \mathrm{wt}$.\% sodium the mechanical properties approach to the values reached for the alloy modified by using 0.05 wt.\% sodium. Adding the combination of strontium plus tellurium into the liquid metal proved to be similar because the mechanical properties of this material did not exceed the level obtained after processing either with tellurium only or strontium only. The low mechanical properties of the material from the ST10 heat (a strength of $118 \mathrm{MPa}$ and ductility of $1.7 \%$ ) correspond to the structure presented in Figure 3f, which is characteristic by the presence of the $\beta$-phase long plates and coarse particles of eutectic Si. Therefore, the combined treatment of $\mathrm{Sr}$ and Te can be considered unsuitable.

As compared to the as-cast state, the heat treatment of the Al-Si alloy modified with additions of $\mathrm{Na}, \mathrm{Te}$, or $\mathrm{Sr}$ as well as those with the combinations of $\mathrm{Na}+\mathrm{Te}$ and $\mathrm{Sr}+\mathrm{Te}$ did not produce more marked changes in the mechanical properties (as is documented in Table 1). 
In accordance with the phase diagram in Figure 1, this has allowed us to express an assumption that the heat treatment of the studied alloys influenced the morphology of the $\beta$-phase $\mathrm{Al}_{5} \mathrm{FeSi}$, and its behavior in the matrix only very little.

A microanalysis of the experimental materials' structure components has shown the characteristic needles of the iron rich phase correspond to the composition of $\mathrm{Al}_{5} \mathrm{FeSi}$ phase in the reference material (E) and in alloys modified with strontium and sodium when both of these elements have been analyzed in the matrix. These findings support a hypothesis that their modification effect is a result of an increase in the surface tension. In contrast, the third additional element (tellurium) occurred only in a trace amount in the matrix and was concentrated in the plate and rodlike precipitates, in which the iron content corresponded more likely to the $\mathrm{Al}_{8} \mathrm{Fe}_{2} \mathrm{Si}$ phase and (in some cases) to the $\mathrm{Al}_{3} \mathrm{FeSi}$ phase. Furthermore, in the Al-Si alloy microstructure modified with tellurium, other unusual phases having an iron content about $14 \mathrm{wt} . \%$ were also found; they will be subjected to future research.

\section{CONCLUSIONS}

The goal of the presented research was to study the possibilities of improving the mechanical properties of the hypoeutectic AlSi9 alloy with an iron content of $1.75 \mathrm{wt} . \%$. It is important to note that the experimental material did not contain the elements capable of producing the substitution and precipitation strengthening of the matrix; therefore, the results document the alternatives for the modifying effect on the $\mathrm{Al}_{5} \mathrm{FeSi}$ phase with a minimum impact on the properties of the basic Al-Si system. The results have pointed out several feasible methods of treatment of the Al-Si alloy contaminated with iron to produce high-quality (or at least usable) material. They present the possibility of processing or modifying the properties of the Al-Si system with an iron content of $1.75 \mathrm{wt} . \%$ using an intervention into the morphology of the $\mathrm{Al}_{5} \mathrm{FeSi}$ phase or its behavior in the matrix using additions of strontium, sodium, and tellurium. The metallographic analysis has proven the good accordance the structural characteristics have with the measured mechanical properties as well as with the initial assumption about the effect of tellurium application and modification with sodium and strontium.

\section{Acknowledgement}

The authors appreciate the financial support provided by Slovak Research and Development Agency for the projects APVV0857-12 and APVV-16-0485.

\section{REFERENCES}

[1] Mondolfo L.F. (1976). Aluminium Alloys: Structure and Properties. London - Boston: Butter Worths.

[2] Lu L. \& Dahle A.K. (2005). Iron-rich intermetallic phases and their role in casting defect formation in hypoeutectic Al-Si alloys. Metallurgical and Materials Transactions A, 36(13), 819-835. doi:10.1007/s11661-005-1012-4

[3] Ashtari P., Tetley-Gerard K. \& Sadayappan K. (2012). Removal of iron from recycled aluminium alloys. Canadian Metallurgical Quarterly, 51(1), 75-80. doi:10.1179/1879139511Y.0000000026

[4] Belov N.A., Aksenov A.A. \& Eskin D.G. (2002). Iron in Aluminum Alloys: Impurity and Alloying Element. London: Taylor \& Francis.

[5] Warmuzek M. (2016). The AlFeMnSi intermetallics competition in the interdendritic eutectics in AISi cast alloys influenced by cooling rate and transition metals content. Prace Instytutu Odlewnictwa, 56(1), 7-16. doi:10.7356/iod.2016.02

[6] Shabestari S.G. (2004). The effect of iron and manganese on the formation of intermetallic compounds in aluminum-silicon alloys. Materials Science and Engineering A, 383 (2), 289-298.

[7] Fortini A., Merlin M., Fabbri E., Pirletti S. \& Garagnani G.L. (2016). On the influence of $\mathrm{Mn}$ and $\mathrm{Mg}$ additions on tensile properties, microstructure and quality index of the A356 aluminum foundry alloy. Procedia Structural Integrity, 2, 2238-2245. doi:10.1016/j.prostr.2016.06.280

[8] Chudokormov D.N., Pilárik S., Galuško A.M., Murgaš M. \& Striženkov M.I. (1988). Vplyv mikrolegovania na vlastnosti silumínov so zvýšeným obsahom železa. Slévárenství, 36(6), 228-230.

[9] Wang M., Xu W. \& Han Q. (2016). Study of Refinement and Morphology Change of AlFeSi Phase in A380 Alloy due to Addition of $\mathrm{Ca}, \mathrm{Sr} / \mathrm{Ca}, \mathrm{Mn}$ and $\mathrm{Mn}$, Sr. Materials Transactions, 57(9), 1509-1513. doi:10.2320/matertrans.M2015329

[10] Suárez-Peña B. \& Asensio-Lozano J. (2006). Influence of Sr modification and Ti grain refinement on the morphology of $\mathrm{Fe}$-rich precipitates in eutectic Al-Si die cast alloys. Scripta Materialia, 54, 1543-1548.

[11] Sigworth G.K. (2008). The Modification of Al-Si Casting Alloys: Important Practical and Theoretical Aspects. International Journal of Metalcasting, 2(2), 19-40. doi: 10.1007/ BF03355425

[12] Mahta M., Emamy M., Cao X. \& Campbell J. (2008). Overview of $\beta-\mathrm{Al}_{5} \mathrm{FeSi}$ phase in $\mathrm{Al}-\mathrm{Si}$ alloys. In: Olivante L.V. (ed.), Materials Science Research Trends. Nova Science Publishers Inc., 251-271.

[13] Zhang L., Gao J., Nana Wiredu Damoah L. \& Robertson D.G. (2012). Removal of iron from aluminum: A review. Mineral Processing and Extractive Metallurgy Review, 33(2), 99-157. doi:10.1080/08827508.2010.542211

[14] Taylor J.A. (2012). Iron-containing intermetallic phases in Al-Si based casting alloys. Procedia Materials Science, 1, 19-33. doi:10.1016/j.mspro.2012.06.004

[15] Tillová E. \& Panušková M. (2008). Effect of solution treatment on intermetallic phases morphology in AlSi9Cu3 cast alloy. Metalurgija, 47(3), 207-210.

[16] Timpel M., Wanderka N., Grothausmann R. \& Banhart J. (2013). Distribution of Fe-rich phases in eutectic grains of $\mathrm{Sr}$-modified Al-10 wt.\% Si-0.1 wt.\% Fe casting alloy. Journal of Alloys and Compounds, 558, 18-25. doi:10.1016/j.jallcom.2012.12.009 